\title{
Depression prevention and mental health promotion interventions: is stigma taken into account? An overview of the Italian initiatives
}

Submitted 12 October 2012; revised 14 January 2013; accepted 15 January 2013; First published online 28 February 2013

\section{Dear Editor}

Depressive disorders represent a major public health concern in European countries and Italian epidemiological studies confirm that despite being highly prevalent in the general population and in clinical settings, their recognition and treatment are often inadequate (Balestrieri et al. 2004). Research suggested that the public stigma of mental disorders (defined as the general public's negative attitudes towards individuals with mental disorders) increases self-stigma (e.g. internalized attitudes held by people suffering from a mental disorder) with the consequences that individuals avoid seeking treatment and increase their social isolation (Kanter et al. 2008). In a survey on the Australian general population (Griffiths et al. 2008), personal stigma was associated with greater current psychological distress and lower depression literacy.

Based on this evidence, the European Union (EU) mental health conference in 2008 launched the European Pact for Mental Health and Well-Being indicating the prevention of depression and suicide and the fight against stigma as priorities for EU members. In Italy, the National Preventive Plan 2010-2012, launched by Ministry of Health, underlined the need to improve early detection of depression, the evaluation of prevention programmes and the use of evidence-based practices. A recent review on Italian anti-stigma campaigns toward mental illness (Zoppei \& Lasalvia, 2011) found that only $12.7 \%$ of these initiatives were promoted at the national level and $80 \%$ were conducted at the local level. Remarkably, the majority of these studies did not report any information on their outcomes or effectiveness and the methodology was often inappropriate. However, the review was focused on campaigns addressing mental disorders in general, rather than depression per se.

* Address for correspondence: Dr M. Lanfredi, Unit of Psychiatry, IRCCS Istituto Centro San Giovanni di Dio Fatebenefratelli, via Pilastroni 4, I-25125, Brescia, Italy.

(Email: mlanfredi@fatebenefratelli.it)
This study aims to review anti-stigma activities in depression prevention programmes delivered to date in Italy in order to evaluate their impact from a public health perspective. Owing to the overlap between prevention and treatment, we considered a broad concept of prevention, including interventions occurring before the onset of depression and those aiming to prevent comorbidity, relapse, disability and the consequences of severe mental illness for families (NIMH, 1998).

\section{Methods}

This study was conducted within the framework of the Anti Stigma Programme European Network (ASPEN), a multisite project aiming to address stigma and discrimination against people with depression (Lasalvia et al. 2013). A detailed report on depression anti-stigma programmes across the ASPEN participating countries is given elsewhere (Quinn et al. 2013), and the findings of this survey as a whole are available at http://www. antistigma.eu.

We first identified studies or publications on prevention interventions towards depression that reported outcomes. When no formal evaluation was carried out, we described only the programmes. Inclusion criteria for studies were: either (a) depression or suicide prevention interventions and/or mental health promotion interventions; or (b) anti-stigma interventions towards depression and/or studies aiming to evaluate opinions and attitudes towards depression; or (c) both (a) and (b); (d) carried out in Italy and (e) written in Italian or in English. A comprehensive literature search of PubMed databases and WEB from January 1995 through July 2012 was conducted.

For the electronic database searches we used all the possible combinations of the following key terms: depression (MeSH Terms) OR mood disorder (MeSH Terms) OR suicide (MeSH Terms) OR mental health AND prevention (Title/Abstract) OR promotion (Title/Abstract) OR stigma (Title/Abstract) OR attitude (Title/Abstract) AND (ital ${ }^{*}$ ). Furthermore, web-based publications were identified through searching specific websites oriented to prevention of depression or 
stigma reduction. Records identified through websearch were included when outcomes were reported on or at least protocols were available; additionally, social events specifically aimed to prevent depression or suicide or fight stigma were included.

We adopted the definitions of universal, selective and indicated prevention, as laid out in the Institute of Medicine Report (1994), excluding any pharmacological interventions. We considered both the prevention of depression and the promotion of mental health. Universal prevention programmes are referred to the entire population, regardless of their risk status. Selective prevention programmes are delivered to potential at-risk populations for the development of depressive or mental-health disorders. Indicated prevention programmes are applied to vulnerable or at-risk populations (i.e. people who display subclinical signs or symptoms of depression). Lastly, we included an additional fourth category named Preventive treatment programmes (adapted from NIMH, 1998) for selected interventions targeting people with a diagnosis of depression in order to prevent chronicity or lethal consequences. Studies targeting people identified with a diagnosis of depression, people who previously attempted suicide or who received treatment in the mental health system were included. Furthermore, we evaluated the use of three strategies that have been widely cited as a method to reduce public stigma of mental illness: Education, Protest and Contact-based education (Corrigan et al. 2012).

\section{Results}

\section{Universal prevention programmes}

One survey on opinions towards depression, seven awareness raising campaigns and 11 school-based interventions were found (Table 1). Anti-stigma activities were conducted in 14 programmes and the two strategies used against stigma were education and contact-based education. In particular, five of these stated stigma reduction as their objective and one aimed to change adolescents' attitudes towards mental illness.

Two studies included service users in their programmes: the multilevel programme delivered in Rovigo conducted a focus group with a stakeholder representative group (young people, older people and individuals after a suicide attempt) for planning the programme in the following executive phase (Poma et al. 2011): two focus groups with patients who attempted suicide (Ghio et al. 2011) in order to understand the main reasons leading to these attempts.
Different types of interventions targeted the general population and focused on two intervention levels: (1) public awareness campaigns to improve public attitudes on depression and help-seeking; (2) training sessions for target groups (i.e. gatekeepers, community facilitators and mental health professionals) to improve referrals of vulnerable people to local mental health services.

Tools used to facilitate public campaigns were: leaflets on help available locally, warning signals and treatment options; websites; open days, seminars, spots; testimonies of famous people who have successfully overcome depression; public events as 'Race for Life'.

Preliminary outcomes about the impact of an awareness campaign were only reported by Giupponi et al. (2008) in the framework of the European Alliance Against Depression (EAAD) prevention project. They conducted a survey based on 1000 questionnaire and 458 interviews among citizens of the Alto Adige Region and findings were compared with studies on public attitudes towards depression conducted in other geographical contexts. However, the lack of preintervention measures did not allow to establish the degree or persistence of the effect. Nine of the educational programmes targeted secondary-school students and five of those included a post-evaluation. Only two studies targeting students focused on prevention of depression: the first delivered by the National Centre for Epidemiology, Surveillance and Health Promotion (CNESP) included a follow-up at 6 months (data not yet available); the second one was an intervention for promoting protective factors against suicide delivered in Rovigo.

The aims of the educational interventions in schools was to increase the knowledge about mental illness and its beneficial effect on consequent public attitudes and to improve resilience and well-being as protective factors for individual positive mental health.

Tools used in the school-based programmes were: video, leaflets on psychiatric terminology, lessons on myths and facts about mental illnesses, a manual on life skills, laboratories and meetings with mental health professionals. Educational methods utilized peer education, interactive activities, role playing, group discussions. Few studies used ad hoc questionnaires for the evaluation of knowledge towards mental disorders at post-intervention or questionnaires on opinions regarding mental disorders.

\section{Selected prevention programmes}

Five programmes targeted groups potentially at risk of suicide or with the presence of a combination of risk factors for mental health problems, two interventions 
Table 1. Characteristics of universal programmes

\begin{tabular}{|c|c|c|c|c|c|c|c|}
\hline $\begin{array}{l}\text { Name of the project } \\
\text { or study's source }\end{array}$ & $\begin{array}{l}\text { Organization } \\
\text { (region) }\end{array}$ & $\begin{array}{l}\text { Anti-stigma } \\
\text { activities }\end{array}$ & Description & Objectives & $\begin{array}{l}\text { Target group } \\
\text { (duration) }\end{array}$ & Main findings & Website \\
\hline $\begin{array}{l}\text { 1. Invito alla vita } \\
\text { (call for life) }\end{array}$ & $\begin{array}{l}\text { Autonomous } \\
\text { Province of } \\
\text { Trento } \\
\text { (Trentino } \\
\text { A. Adige) }\end{array}$ & Education & $\begin{array}{l}\text { Two informative } \\
\text { campaigns; seminars } \\
\text { for medical and nurse } \\
\text { professionals }\end{array}$ & $\begin{array}{l}\text { Warning signals' } \\
\text { detection }\end{array}$ & $\begin{array}{l}\text { General } \\
\text { population, } \\
\text { community } \\
\text { facilitators } \\
\text { (2009-2010) }\end{array}$ & & $\begin{array}{l}\text { Retrieved } 5 \text { May } 2012 \text { from http:// } \\
\text { www.azisanrovigo.it }\end{array}$ \\
\hline $\begin{array}{l}\text { 2. Evaluation and } \\
\text { applying } \\
\text { programmes for } \\
\text { suicide } \\
\text { prevention with } \\
\text { the cooperation } \\
\text { of stakeholders }\end{array}$ & $\begin{array}{l}\text { LHU of Rovigo } \\
\text { (Veneto) }\end{array}$ & Education & $\begin{array}{l}\text { Multilevel approach: } \\
\text { survey on depression; } \\
\text { focus group and } \\
\text { informative trainings } \\
\text { for stakeholders; } \\
\text { school-based } \\
\text { programme, website }\end{array}$ & $\begin{array}{l}\text { Identify main } \\
\text { barriers to } \\
\text { accessing care; } \\
\text { promotion of } \\
\text { students' } \\
\text { well-being }\end{array}$ & $\begin{array}{l}\text { General } \\
\text { population, } \\
\text { stakeholders, } \\
\text { students } \\
\text { (2009-2011) }\end{array}$ & $\begin{array}{l}1200 \text { interviews on } \\
\text { suicide (A. Grossi, } \\
\text { personal } \\
\text { communication, } \\
\text { 2011) }\end{array}$ & $\begin{array}{l}\text { Retrieved } 10 \text { May } 2012 \text { from http:// } \\
\text { www.azisanrovigo.it and http:// } \\
\text { www.perdersidanimomai.it }\end{array}$ \\
\hline 3. Ghio et al. (2011) & $\begin{array}{l}\text { University of San } \\
\text { Martino } \\
\text { (Liguria) }\end{array}$ & No & $\begin{array}{l}\text { Qualitative research on } \\
\text { suicide attempters' } \\
\text { experiences }\end{array}$ & $\begin{array}{l}\text { Identify risk and } \\
\text { protective } \\
\text { factors }\end{array}$ & $\begin{array}{l}\text { Suicide } \\
\text { attempters } \\
\text { (NA) }\end{array}$ & $\begin{array}{l}\text { Interpersonal } \\
\text { relationships and } \\
\text { empathy as } \\
\text { protective factors }\end{array}$ & \\
\hline $\begin{array}{l}\text { 4. European } \\
\text { Depression Day }\end{array}$ & EDA onlus & Education & $\begin{array}{l}\text { Aware campaign: annual } \\
\text { meetings }\end{array}$ & $\begin{array}{c}\text { Awareness on } \\
\text { depression }\end{array}$ & $\begin{array}{l}\text { General } \\
\text { population } \\
\text { (since 2008) }\end{array}$ & NA & $\begin{array}{l}\text { Retrieved } 10 \text { April } 2012 \text { from http:// } \\
\text { www.edaitalia.org }\end{array}$ \\
\hline $\begin{array}{l}\text { 5. World Suicide } \\
\text { Prevention Day }\end{array}$ & $\begin{array}{l}\text { St. Andrea } \\
\text { Hospital of } \\
\text { Rome, IASPS } \\
\text { (Lazio) }\end{array}$ & Education & $\begin{array}{l}\text { Aware campaign: } \\
\text { conferences, media, } \\
\text { marathon 'Race for } \\
\text { life'; media guideline } \\
\text { for reporting suicide }\end{array}$ & $\begin{array}{l}\text { Awareness on } \\
\text { suicide }\end{array}$ & $\begin{array}{l}\text { General } \\
\text { population } \\
\text { (since 2008) }\end{array}$ & NA & $\begin{array}{l}\text { Retrieved } 30 \text { May } 2012 \text { from http:// } \\
\text { www. } \\
\text { raceforlife-prevenzione-suicidio.it }\end{array}$ \\
\hline $\begin{array}{l}\text { 6. Depressive } \\
\text { diseases }\end{array}$ & $\begin{array}{l}\text { ARETE Ass. } \\
\text { (Lombardy) }\end{array}$ & Education & $\begin{array}{l}\text { Informative brochures, } \\
\text { website }\end{array}$ & $\begin{array}{c}\text { Awareness on } \\
\text { depression }\end{array}$ & $\begin{array}{l}\text { General } \\
\text { population } \\
\text { (NA) }\end{array}$ & NA & $\begin{array}{l}\text { Retrieved } 12 \text { April } 2012 \text { from http:// } \\
\text { www.depressionearete.it/stampa. } \\
\text { htm }\end{array}$ \\
\hline $\begin{array}{l}\text { 7. Depression and } \\
\text { anxiety } \\
\text { disorders: ask for } \\
\text { help, do not be } \\
\text { afraid }\end{array}$ & $\begin{array}{l}\text { Ministry of Equal } \\
\text { Opportunities } \\
\text { (Lazio) }\end{array}$ & Education & Congress on depression & $\begin{array}{l}\text { Awareness on } \\
\text { depression and } \\
\text { stigma }\end{array}$ & $\begin{array}{l}\text { General } \\
\text { population } \\
(2009)\end{array}$ & NA & $\begin{array}{l}\text { Retrieved } 10 \text { June } 2012 \text { from http:// } \\
\text { www.pariopportunita.gov.ita }\end{array}$ \\
\hline
\end{tabular}


Table 1. Continued

\begin{tabular}{|c|c|c|c|c|c|c|c|}
\hline $\begin{array}{l}\text { Name of the project } \\
\text { or study's source }\end{array}$ & $\begin{array}{l}\text { Organization } \\
\text { (region) }\end{array}$ & $\begin{array}{l}\text { Anti-stigma } \\
\text { activities }\end{array}$ & Description & Objectives & $\begin{array}{l}\text { Target group } \\
\text { (duration) }\end{array}$ & Main findings & Website \\
\hline 8. A smile for moms & ONDa & Education & $\begin{array}{l}\text { National informative } \\
\text { campaign: spots, } \\
\text { conferences, website }\end{array}$ & $\begin{array}{l}\text { Awareness on } \\
\text { post-partum } \\
\text { depression }\end{array}$ & Women (2012) & NA & $\begin{array}{l}\text { Retrieved } 3 \text { May } 2012 \text { from http:// } \\
\text { www.depressionepostpartum.it }\end{array}$ \\
\hline 9. EAAD Project & $\begin{array}{l}\text { European } \\
\text { Commission } \\
\text { (Alto Adige) }\end{array}$ & Education & $\begin{array}{l}\text { Regional public } \\
\text { awareness campaigns } \\
\text { and cooperation with } \\
\text { media; training for } \\
\text { community facilitators. }\end{array}$ & $\begin{array}{l}\text { Awareness on } \\
\text { depression and } \\
\text { suicide }\end{array}$ & $\begin{array}{l}\text { General } \\
\text { population } \\
(2008)\end{array}$ & $\begin{array}{l}\text { More positive } \\
\text { attitudes towards } \\
\text { depression; } \\
\text { negative opinion } \\
\text { on drugs in } \\
\text { national and } \\
\text { international } \\
\text { contexts }\end{array}$ & $\begin{array}{l}\text { Retrieved } 3 \text { May } 2012 \text { from http:// } \\
\text { www.eaad.net/ }\end{array}$ \\
\hline $\begin{array}{l}\text { 10. Ruini et al. } \\
\text { (2009) }\end{array}$ & $\begin{array}{l}\text { University of } \\
\text { Bologna } \\
\text { (Emilia } \\
\text { Romagna) }\end{array}$ & No & RCT & $\begin{array}{l}\text { Improve } \\
\text { psychological } \\
\text { well-being }\end{array}$ & Students (NA) & $\begin{array}{l}\text { Improvement in } \\
\text { 'personal growth' } \\
\text { as measured by } \\
\text { PWB scale, at } 6 \\
\text { months follow-up }\end{array}$ & \\
\hline $\begin{array}{l}\text { 11. Development of } \\
\text { an intervention } \\
\text { in schools, with } \\
\text { particular } \\
\text { attention to } \\
\text { primary } \\
\text { prevention of } \\
\text { depression }\end{array}$ & CNESP & Education & $\begin{array}{l}\text { Psycho-educational } \\
\text { sessions: peer } \\
\text { education, structured } \\
\text { manual on life skills. } \\
\text { Controlled study. }\end{array}$ & $\begin{array}{c}\text { Prevention of } \\
\text { depression }\end{array}$ & $\begin{array}{l}\text { Students }(2007- \\
\text { 2012) }\end{array}$ & Still in progress & $\begin{array}{l}\text { Retrieved } 10 \text { May } 2012 \text { from http:// } \\
\text { www.ccm-network.it }\end{array}$ \\
\hline $\begin{array}{l}\text { 12. Fuori come va? } \\
\text { (How goes it?) }\end{array}$ & $\begin{array}{l}\text { LHU } 15 \text { of Cuneo } \\
\text { (Piemonte) }\end{array}$ & Education & $\begin{array}{l}\text { Laboratories and } \\
\text { interpersonal contacts }\end{array}$ & Change attitudes & $\begin{array}{l}\text { Students (2004- } \\
\text { 2005) }\end{array}$ & NA & $\begin{array}{l}\text { Retrieved } 10 \text { March } 2012 \text { from http:// } \\
\text { www.retepromozionesalute.it }\end{array}$ \\
\hline $\begin{array}{l}\text { 13. National } \\
\text { Programme of } \\
\text { Communication } \\
\text { and Information } \\
\text { against Stigma } \\
\text { and Prejudice in }\end{array}$ & $\begin{array}{l}\text { Ministry of } \\
\text { Health } \\
\text { (Lombardy, } \\
\text { Veneto) }\end{array}$ & Education & $\begin{array}{l}\text { Brescia: informative } \\
\text { materials and meetings } \\
\text { for students and } \\
\text { teachers. Pre-post } \\
\text { design }\end{array}$ & Reduce stigma & $\begin{array}{l}\text { Students (2005- } \\
\text { 2006) }\end{array}$ & $\begin{array}{l}\text { Reduction of social } \\
\text { stigma, } \\
\text { improvement of } \\
\text { knowledge of } \\
\text { mental illness at } 6 \\
\text { months follow-up }\end{array}$ & $\begin{array}{l}\text { Retrieved } 10 \text { April } 2012 \text { from http:// } \\
\text { www.campagnastigma.it/ } \\
\text { campagnastigma/index.html }\end{array}$ \\
\hline
\end{tabular}

MH (Grossi \&

Toniolo, 2006) 


\begin{tabular}{|c|c|c|c|c|c|c|c|}
\hline $\begin{array}{l}\text { 14. Fight to stigma } \\
\text { and mental } \\
\text { illness }\end{array}$ & $\begin{array}{l}\text { LHU of Mirano } \\
\text { (Veneto) }\end{array}$ & Education & $\begin{array}{l}\text { Psycho-educational } \\
\text { interventions, pre-post } \\
\text { design }\end{array}$ & Reduce stigma & Students (2007) & NA & \\
\hline $\begin{array}{l}\text { 15. Chiamatemi per } \\
\text { nome (Call me by } \\
\text { name) }\end{array}$ & $\begin{array}{l}\text { LHU of Perugia } \\
\text { (Umbria) }\end{array}$ & Education & $\begin{array}{l}\text { Meetings with } \\
\text { professionals, } \\
\text { laboratories, pre-post } \\
\text { evaluation }\end{array}$ & $\begin{array}{l}\text { Health education } \\
\text { promotion }\end{array}$ & Students (2007) & $\begin{array}{l}\text { Leaflets on mental } \\
\text { illness (2012) }\end{array}$ & $\begin{array}{l}\text { Retrieved } 10 \text { April } 2012 \text { from http:// } \\
\text { www.retepromozionesalute.it }\end{array}$ \\
\hline $\begin{array}{l}\text { 16. Siamo tutti un } \\
\text { po' matti o siamo }^{\prime} \\
\text { tutti un po' sani? } \\
\text { (Are we a little } \\
\text { crazy or a little } \\
\text { healthy?) }\end{array}$ & $\begin{array}{l}\text { LHU Collegno } \\
\text { (Piemonte) }\end{array}$ & Education & $\begin{array}{l}\text { Dance movement } \\
\text { protocol, pre-post } \\
\text { evaluation }\end{array}$ & Reduce stigma & $\begin{array}{l}\text { Students (2006- } \\
\text { 2007) }\end{array}$ & NA & $\begin{array}{l}\text { Retrieved } 10 \text { April } 2012 \text { from http:// } \\
\text { www.retepromozionesalute.it/ }\end{array}$ \\
\hline $\begin{array}{l}\text { 17. Castiello \& } \\
\text { Magliano (2007) }\end{array}$ & $\begin{array}{l}\text { University of } \\
\text { Naples SUN } \\
\text { (Campania) }\end{array}$ & No & $\begin{array}{l}\text { Comparative study with } \\
\text { case vignettes about } \\
\text { schizophrenia and } \\
\text { depression }\end{array}$ & $\begin{array}{l}\text { Description of } \\
\text { student's } \\
\text { opinions }\end{array}$ & Students (NA) & $\begin{array}{l}\text { PMI was described as } \\
\text { unpredictable and } \\
\text { dangerous }\end{array}$ & \\
\hline
\end{tabular}

NA, not applicable or not available; PMI, people with mental illness; MH, mental health; RCT, randomized controlled clinical trial.

Note: All references cited in the tables are available from the authors upon request. 
supporting family members of people who committed suicide and a psychological consultation service for the general population were found (Table 2). There were various interventions oriented to facilitate access to professional help: crisis hotlines for elderly people, services and self-help activities for suicide bereavement and websites.

The educational strategy was used in the EAAD project in order to facilitate the access to care indirectly (i.e. seminars to facilitate cooperation between mental health professionals or to improve their abilities in detecting and managing people at risk). Lastly, a pilot study (Molinari et al. 2012) promoted a psychological consulting service in the neighbourhood aiming to reduce economic and proximity barriers. During the 2009-2011 period, 17\% of service attendees reported depressive symptoms. None of the programmes included instruments for evaluating stigma reduction.

\section{Indicated prevention programmes}

These programmes aimed to screen high risk factors before the occurrence of a mental disorder (i.e. major depression or post-partum depression) (Table 2). We found only one programme aimed to improve identifying at-risk individuals for post-partum depression. This prospective comparison group study evaluated the efficacy of a preventive welfare programme: risk and vulnerability factors were measured and a brief psychotherapeutic intervention was delivered. Antistigma activities were not reported.

\section{Preventive treatment programmes}

Table 3 summarizes two interventions of screening for depression, two studies aimed to reduce relapse and a family support project. Anti-stigma activities or stigma measurements were not stated.

The screening interventions aimed to improve early detection and best management of mental health service users and general practice attendees, without any outcome measures about their indirect impact on stigma reduction. The 'G. Leggieri Programme' (Rucci et al. 2012) represented an initiative to promote integration between primary care and mental health services. Data indicated that among patients in contact with psychiatric services in Emilia Romagna, those less often referred by GPs were young adults living in the urban area and who were suffering from a depressive disorder.

Moreover, three different types of interventions for preventing relapse were conducted and none promoted anti-stigma activities. They targeted patients with recurrent depression, caregivers and adolescents with suicidal attempts. In particular, in the context of the 'Acute treatment of adolescents with attempted suicide' programme, after admission to the emergency rooms, adolescents are hospitalized into the Paediatric Department because it is less stigmatizing than psychiatric settings and a specific protocol is used.

\section{Discussion}

The present overview summarizes the Italian programmes and campaigns for preventing depression and promoting mental health and our main aim was to assess whether anti-stigma activities were included.

Despite the National Health Plan 2006-2008 underlining the need to improve anti-stigma programmes, we noted a lack of specific national guidelines about best practice. We found that most Italian prevention programmes did not address public stigma nor internalized stigma related to depression; equally their impact on help-seeking for depression has not yet been adequately investigated. Moreover, prevention programmes which focused on reducing social stigma mainly targeted the general public (the wider public or target groups) and used education or personal contacts as strategies. Our data on anti-stigma programmes are consistent with those of Zoppei \& Lasalvia (2011) indicating a low rate of anti-stigma programmes with outcomes evaluation (25\%).

Despite the development of several instruments to support anti-stigma evaluations (Brohan et al. 2010), it should be underlined that few established scales to measure stigma have been employed. Scocco et al. (2012) reported the progressive internalization of the stigma towards suicide in people with a mental illness compared with the general population. A specific evaluation of the impact of anti-stigma activities would lead to the introduction of evidence-based interventions in prevention programmes that should be disseminated from a local level to a regional or national level. This topic is particularly relevant since negative attitudes and inadequate knowledge on depression may act as barriers to get care (Barney et al. 2006). In Italy, we observed an increasing attention to promote public awareness of depression or suicide, whereas, to our knowledge, no campaigns exist specifically aiming to decrease stigma of depression. This may suggest either a lack of appreciation of the importance of stigma as a barrier to help-seeking for suicide and depression or the lack of attention given to depression within anti-stigma work, which tends to be more focused on stigma of other severe mental disorders. The campaigns were conducted mainly at the local or regional level, whereas in other countries, national campaigns such as the 'Defeat Depression Campaign' in the UK 
Table 2. Characteristics of selective and indicated programmes

\begin{tabular}{|c|c|c|c|c|c|c|c|c|}
\hline & $\begin{array}{l}\text { Name of the project } \\
\text { or study's source }\end{array}$ & $\begin{array}{l}\text { Organization } \\
\text { (region) }\end{array}$ & $\begin{array}{l}\text { Anti-stigma } \\
\text { activities }\end{array}$ & Description & Objectives & $\begin{array}{l}\text { Target group } \\
\text { (duration) }\end{array}$ & Main findings & Website \\
\hline \multirow[t]{5}{*}{ Selective } & 1. EAAD Project & $\begin{array}{l}\text { European } \\
\text { Commission } \\
\text { (South Tyrol) }\end{array}$ & Education & $\begin{array}{l}\text { Multilevel approach: } \\
\text { cooperation with } \\
\text { GPs, psychologists } \\
\text { and chemists; } \\
\text { self-help groups; } \\
\text { telephone } \\
\text { counselling }\end{array}$ & $\begin{array}{l}\text { Prevention of } \\
\text { suicide }\end{array}$ & $\begin{array}{l}\text { People at risk for } \\
\text { suicide (2005- } \\
\text { 2007) }\end{array}$ & $\begin{array}{l}\text { Decrease of suicide rate } \\
\text { from } 18.5 \text { to } 14.5 \% \text { in } \\
\text { men before (2001- } \\
\text { 2003) and during the } \\
\text { EAAD project } \\
\text { (2005-2007) (R. } \\
\text { Pycha and } \\
\text { G. Kemmler, } \\
\text { personal } \\
\text { communication, } \\
\text { 2010) }\end{array}$ & $\begin{array}{l}\text { Retrieved } 10 \text { April } \\
2012 \text { from http:// } \\
\text { www.eaad.net/ }\end{array}$ \\
\hline & $\begin{array}{l}\text { 2. Evaluation and } \\
\text { applying } \\
\text { programmes of } \\
\text { prevention of } \\
\text { suicide with the } \\
\text { cooperation of } \\
\text { stakeholders }\end{array}$ & $\begin{array}{l}\text { LHU } 18 \text { of Rovigo } \\
\text { (Veneto) }\end{array}$ & No & $\begin{array}{l}\text { Multilevel approach: } \\
\text { help-line for elderly } \\
\text { people and support } \\
\text { groups for survivors }\end{array}$ & $\begin{array}{l}\text { Facilitate } \\
\text { accessing to } \\
\text { care }\end{array}$ & $\begin{array}{l}\text { Older people and } \\
\text { high-risk } \\
\text { groups (2009- } \\
\text { 2011) }\end{array}$ & NA & $\begin{array}{l}\text { Retrieved } 5 \text { May } 2012 \\
\text { from http://www. } \\
\text { azisanrovigo.it }\end{array}$ \\
\hline & $\begin{array}{l}\text { 3. Invito alla vita } \\
\text { (Call for life) }\end{array}$ & $\begin{array}{l}\text { Autonomous } \\
\text { Province of } \\
\text { Trento } \\
\text { (Trentino } \\
\text { A. Adige) }\end{array}$ & No & $\begin{array}{l}\text { Crisis Hotline; self-help } \\
\text { groups for survivors; } \\
\text { monitoring system in } \\
\text { MH departments }\end{array}$ & $\begin{array}{l}\text { Prevention of } \\
\text { suicide }\end{array}$ & $\begin{array}{l}\text { People at risk for } \\
\text { suicide (2009- } \\
\text { 2010) }\end{array}$ & NA & $\begin{array}{l}\text { Retrieved } 3 \text { May } 2012 \\
\text { from http://www. } \\
\text { apss.tn.it/public/ } \\
\text { ddw.aspx?n=49082 }\end{array}$ \\
\hline & $\begin{array}{l}\text { 4. Prevenire il } \\
\text { suicidio } \\
\text { (Prevention of } \\
\text { suicide) }\end{array}$ & $\begin{array}{l}\text { St. Andrea } \\
\text { Hospital of } \\
\text { Rome (Lazio) }\end{array}$ & No & Help-line, website & $\begin{array}{l}\text { Prevention of } \\
\text { suicide }\end{array}$ & $\begin{array}{l}\text { Elderly people at } \\
\text { risk (NA) }\end{array}$ & NA & $\begin{array}{l}\text { Retrieved } 15 \text { May } 2012 \\
\text { from http://www. } \\
\text { prevenireilsuicidio.it }\end{array}$ \\
\hline & 5. De Leo et al. (2002) & $\begin{array}{l}\text { Government } \\
\text { sponsored } \\
\text { (Veneto) }\end{array}$ & No & $\begin{array}{l}\text { Tele-Help and } \\
\text { Tele-Check system }\end{array}$ & $\begin{array}{l}\text { Prevention of } \\
\text { suicide }\end{array}$ & $\begin{array}{l}\text { Elderly people } \\
\text { (NA) }\end{array}$ & $\begin{array}{l}\text { Lower than expected } \\
\text { suicide rates among } \\
\text { people over } 65 \text { years } \\
\text { old than general } \\
\text { population, at } 4 \\
\text { years follow-up. }\end{array}$ & \\
\hline
\end{tabular}


Table 2. Continued

\begin{tabular}{|c|c|c|c|c|c|c|c|c|}
\hline & $\begin{array}{l}\text { Name of the project } \\
\text { or study's source }\end{array}$ & $\begin{array}{l}\text { Organization } \\
\text { (region) }\end{array}$ & $\begin{array}{l}\text { Anti-stigma } \\
\text { activities }\end{array}$ & Description & Objectives & $\begin{array}{l}\text { Target group } \\
\text { (duration) }\end{array}$ & Main findings & Website \\
\hline & 6. SOPRoxi project & Padua (Veneto) & No & Dedicated service & $\begin{array}{l}\text { Supportive } \\
\text { intervention }\end{array}$ & $\begin{array}{l}\text { Survivors (2006- } \\
\text { 2012) }\end{array}$ & NA & \multirow[t]{2}{*}{$\begin{array}{l}\text { Retrieved } 20 \text { May } 2012 \\
\text { from http://www. } \\
\text { soproxi.it }\end{array}$} \\
\hline & $\begin{array}{l}\text { 7. The psychologist } \\
\text { in the } \\
\text { neighbourhood } \\
\text { project }\end{array}$ & $\begin{array}{l}\text { Catholic } \\
\text { University of } \\
\text { Milan, Health } \\
\text { Department of } \\
\text { Milan, } \\
\text { FederFarma, } \\
\text { ADMENTA } \\
\text { (Lombardy) }\end{array}$ & No & $\begin{array}{l}\text { Pilot study of a new } \\
\text { psychological } \\
\text { consultation service: } \\
\text { free psychological } \\
\text { consultations in } 28 \\
\text { chemist's shops in } \\
\text { Milan }\end{array}$ & $\begin{array}{l}\text { Prevention of } \\
\text { psychological } \\
\text { diseases }\end{array}$ & $\begin{array}{l}\text { Chemists' users } \\
\text { with } \\
\text { unexpressed } \\
\text { psychological } \\
\text { needs (2009- } \\
\text { 2011) }\end{array}$ & $\begin{array}{l}\text { After a series of } \\
\text { consultations, } 78 \% \\
\text { of participants were } \\
\text { redirected to } \\
\text { territorial services or } \\
\text { resolved their } \\
\text { problems; } 22.1 \% \\
\text { dropped out }\end{array}$ & \\
\hline Indicated & $\begin{array}{l}\text { 1. Detection and } \\
\text { prevention of } \\
\text { post-partum } \\
\text { depression }\end{array}$ & $\begin{array}{l}\text { Trento's } \\
\text { Provincial } \\
\text { Health Services } \\
\text { (Trentino } \\
\text { A. Adige) }\end{array}$ & No & $\begin{array}{l}\text { Evaluation of risk and } \\
\text { vulnerability factors; } \\
\text { brief } \\
\text { psychotherapeutic } \\
\text { intervention }\end{array}$ & $\begin{array}{l}\text { Prevention of } \\
\text { post-partum } \\
\text { depression }\end{array}$ & $\begin{array}{l}\text { Women before } \\
\text { and after } \\
\text { delivery (2007- } \\
\text { 2010) }\end{array}$ & NA & $\begin{array}{l}\text { Retrieved } 15 \text { May } 2012 \\
\text { from http://www. } \\
\text { asplazio.it/ }\end{array}$ \\
\hline
\end{tabular}

NA, not applicable or not available; PMI, people with mental illness; MH, mental health; RCT, randomized controlled clinical trial.

Note: All references cited in the tables are available from the authors upon request. 
Table 3. Characteristics of preventive treatment programmes

\begin{tabular}{|c|c|c|c|c|c|c|c|}
\hline $\begin{array}{l}\text { Name of the } \\
\text { project or } \\
\text { study's source }\end{array}$ & $\begin{array}{l}\text { Organization } \\
\text { (region) }\end{array}$ & $\begin{array}{l}\text { Anti-stigma } \\
\text { activities }\end{array}$ & Description & Objectives & $\begin{array}{l}\text { Target group } \\
\text { (duration) }\end{array}$ & Main findings & Website \\
\hline $\begin{array}{l}\text { 1. SET_DEP } \\
\text { project }\end{array}$ & $\begin{array}{l}\text { National Agency for } \\
\text { Provincial Health } \\
\text { Services (Lazio) }\end{array}$ & No & $\begin{array}{l}\text { Randomized controlled } \\
\text { trial: screening and } \\
\text { depression } \\
\text { management } \\
\text { intervention }\end{array}$ & $\begin{array}{l}\text { Primary care } \\
\text { screening of } \\
\text { depression }\end{array}$ & $\begin{array}{l}\text { Clinical } \\
\text { practice's } \\
\text { attenders } \\
(2006-2009)\end{array}$ & $\begin{array}{l}\text { The screening showed to } \\
\text { be feasible for a } \\
\text { sample of } 263 \text { patients, } \\
\text { no significant } \\
\text { differences between } \\
\text { two experimental } \\
\text { conditions were found }\end{array}$ & $\begin{array}{l}\text { Retrieved } 30 \text { May } 2012 \text { from http:// } \\
\text { www.agenas.it/agenas_pdf/ } \\
\text { Efficacia\%20nella\%20pratica\% } \\
\text { 20e\%20rapporto\%20costi\% } \\
\text { 20benefici.pdf }\end{array}$ \\
\hline $\begin{array}{l}\text { 2. G. Leggieri } \\
\text { Programme } \\
\text { (Rucci et al. } \\
\text { 2012) }\end{array}$ & $\begin{array}{l}\text { Emilia Romagna } \\
\text { Region }\end{array}$ & No & $\begin{array}{l}\text { Diagnostic assessment, } \\
\text { brief focused } \\
\text { therapeutic } \\
\text { interventions and } \\
\text { consultation-liaison } \\
\text { activities }\end{array}$ & $\begin{array}{l}\text { Improve GPs } \\
\text { management of } \\
\text { patients with } \\
\text { common } \\
\text { psychiatric } \\
\text { disorders }\end{array}$ & $\begin{array}{l}\text { Service users } \\
\text { (1999 to date) }\end{array}$ & $\begin{array}{l}\text { Growing proportion of } \\
\text { GPs referred patients } \\
\text { to specialists in 1999- } \\
2004 \text { period in Bologna } \\
\text { and increased from } \\
51.5 \text { to } 62.2 \% \text { in } 2007- \\
2009 \text { period }\end{array}$ & $\begin{array}{l}\text { Retrieved } 20 \text { May } 2012 \text { from http:// } \\
\text { www.wpanet.org/detail.php? } \\
\text { section_id=7\&content_id=739 }\end{array}$ \\
\hline 3. Fava (2004) & $\begin{array}{l}\text { Affective Disorders } \\
\text { Programme of } \\
\text { University of } \\
\text { Bologna (Emilia } \\
\text { Romagna) }\end{array}$ & No & $\begin{array}{l}\text { Sequential treatment for } \\
\text { depression }\end{array}$ & $\begin{array}{l}\text { Six-year } \\
\text { follow-up of } \\
\text { cognitive } \\
\text { behavioural } \\
\text { treatment } v \text {. } \\
\text { CM }\end{array}$ & $\begin{array}{l}\text { Forty patients } \\
\text { with recurrent } \\
\text { major } \\
\text { depression }\end{array}$ & $\begin{array}{l}\text { Significantly lower level } \\
\text { of residual symptoms } \\
\text { after drug } \\
\text { discontinuation and a } \\
\text { lower relapse rate of } \\
\text { the experimental } \\
\text { group at 2- and 6-year } \\
\text { follow-up. }\end{array}$ & \\
\hline $\begin{array}{l}\text { 4. Acute } \\
\text { treatment of } \\
\text { adolescents } \\
\text { with } \\
\text { attempted } \\
\text { suicide }\end{array}$ & $\begin{array}{l}\text { Fatebenefratelli and } \\
\text { Oftalmico } \\
\text { Hospital of Milan } \\
\text { (Lombardy } \\
\text { Region funded) }\end{array}$ & No & $\begin{array}{l}\text { Specific treatment after } \\
\text { suicide attempt }\end{array}$ & $\begin{array}{l}\text { Relapses' } \\
\text { prevention }\end{array}$ & $\begin{array}{l}\text { Adolescents } \\
\text { (aged 13-21 } \\
\text { years) who } \\
\text { attempted } \\
\text { suicide (2006- } \\
\text { 2008) }\end{array}$ & & \\
\hline
\end{tabular}


(Paykel et al. 1998) or the Australian depression initiative 'Beyondblue', demonstrated a positive impact on decreasing depression-related stigma (Jorm et al. 2005).

The identification of adequate contexts to perform anti-stigma and prevention programmes is a key point. Schools seem to be a suitable setting to promote resilience and education may produce short-term improvements in adolescents' attitudes towards mental illness (Watson et al. 2004). In Italy, school-based interventions are generally based on mental health promotion interventions or programmes of primary prevention for behavioural or emotional problems. Their universal approach might be less stigmatizing for students at risk compared with more individualized interventions; however, their efficacy should be evaluated using more rigorous study designs. In fact, some studies reported positive short-term change on attitudes and knowledge, but their long-term impact is unknown.

Experienced stigma and self-stigma are assumed to be barriers that delay the access to psychiatric services (Aromaa et al. 2011) and discourage people from continuing to get help for a mental health problem. The Italian Mental Health Epidemiological Surveillance system (SEME) found that median interval between the onset of psychiatric symptoms and the first contact with services was 2 years for patients with a major depressive episode with psychotic symptoms or suicide attempt (Gigantesco et al. 2012). This highlights the need to improve early detection of people at risk of severe depression symptoms and that primary care could have a key role in facilitating the access to services.

In addition, stigma associated with receiving care for a mental health problem might have a detrimental effect. In fact, the assessment of depression related stigma in primary care settings, revealed that patients reporting stigma were less likely to be able to manage their depression and had a higher number of missed scheduled appointment visits (Vega et al. 2010). For this reason, the assessment of anticipated and experienced stigma should be beneficial to improve preventive programmes against relapse and to increase help-seeking during a crisis.

Previous studies (Warner, 2008) highlighted the advantages of establishing a multidisciplinary local action committee, selecting a specific social target group and defining measurable goals. These aspects should be deepened in order to develop specific and practicable strategies for the wider Italian context.

Some limitations of the present study should be considered. Our data are mainly based on web resources and the heterogeneity of selected programmes did not allow us to perform a comparative analysis. Moreover, the lack of outcome measures prevents us from reaching clear-cut conclusions in terms of efficacy or costeffectiveness of the identified programmes. Further 
studies will need to assess the impact of depression preventive programmes on stigma reduction by using specific instruments including more comprehensive samples of people at different risk levels for depression. As recommended by Hogan et al. (2002), multilevel programmes involving a complex network of health professionals, caregivers and community target groups should be preferred for their impact on the different components of the process of discrimination. However, in order to optimize resource utilization, the possible synergies and the relative impact of interventions within multilevel approaches should be ascertained with controlled studies and longer follow-up.

\section{Acknowledgements}

\section{The ASPEN Study Group}

Staff at Co-ordinating Centres: Graham Thornicroft, Tine Van Bortel, Samantha Treacy, Elaine Brohan, Shuntaro Ando, Diana Rose (King's College London, Institute of Psychiatry, London, England); Kristian Wahlbeck, Esa Aromaa, Johanna Nordmyr, Fredrica Nyqvist, Carolina Herberts (National Institute for Health and Welfare, Vaasa, Finland); Oliver Lewis, Jasna Russo, Dorottya Karsay, Rea Maglajlic (Mental Disability Advocacy Centre, Budapest, Hungary); Antonio Lasalvia, Silvia Zoppei, Doriana Cristofalo, Chiara Bonetto (Department of Public Health and Community Medicine, Section of Psychiatry and Clinical Psychology, University of Verona, Italy); Isabella Goldie, Lee Knifton, Neil Quinn (Mental Health Foundation, Glasgow, Scotland); Norman Sartorius (Association for the improvement of mental health programmes (AMH), Geneva, Switzerland).

Staff at Partner Centres: Chantal Van Audenhove, Gert Scheerder, Else Tambuyzer (Katholieke Universiteit Leuven (K.U. Leuven), Belgium; Valentina Hristakeva, Dimitar Germanov (Global Initiative on Psychiatry Sofia (GIP-Sofia), Bulgaria); Jean Luc Roelandt, Simon Vasseur Bacle, Nicolas Daumerie, Aude Caria (Etablissement Public Santé Mentale Lille-Métropole (EPSM/C.C.OMS), France); Harald Zaske, Wolfgang Gaebel (Heinrich-Heine Universitat Dusseldorf, Rheinische Kliniken Dusseldorf (RKD), Germany); Marina Economou, Eleni Louki, Lily Peppou, Klio Geroulanou (University Mental Health Institute (UMHRI (EPIPSI), Greece); Judit Harangozo, Julia Sebes, Gabor Csukly (Awakenings Foundation (AWF), Hungary); Giuseppe Rossi, Mariangela Lanfredi, Laura Pedrini (Unit of Psychiatry, IRCCS Istituto Centro San Giovanni di Dio Fatebenefratelli di Brescia, Italy); Arunas Germanavicius, Natalja Markovskaja, Vytis Valantinas (Vilnius University (VU), Lithuania); Jaap van Weeghel, Jenny Boumans, Eleonoor Willemsen, Annette Plooy (Stichting Kenniscentrum Phrenos (KcP), Netherlands); Teresa
Duarte, Fatima Jorge Monteiro (Associação para o Estudo e Integração Psicossocial (AEIPS), Portugal); Janka Hurova, Dita Leczova (Association for Mental Health INTEGRA, o. z. (Integra o.z.), Slovakia); Vesna Svab, Nina Konecnik (University Psychiatric Hospital (PKL), Slovenia); Alp Ucok, Gulsah Karaday (Foundation of Psychiatry Clinic of Medical Faculty of Istanbul (PAP), Turkey).

GT is a member of the NIHR Biomedical Research Centre at the South London and Maudsley NHS Foundation Trust/Institute of Psychiatry (King's College London), and receives support for an Applied Research Programme from the National Institute for Health Research, UK. GT is an Honorary Professor at the University of KwaZulu Natal in Durban. TVB is affiliated with King's College London and University College London, United Kingdom. KW, FN, EA and $\mathrm{CH}$ are affiliated with the National Institute for Health and Welfare (THL), Vaasa, Finland.

\section{Financial support}

This work arises from the project Anti Stigma Programme European Network (ASPEN) which was co-funded by the European Union in the framework of the Public Health Programme (EU Grant Agreement Number: 2007 301).

\section{Conflict of Interest}

None.

M. Lanfredi ${ }^{1}{ }^{,}$, G. Rossi ${ }^{1}$, R. Rossi ${ }^{1}$, T. Van Bortel ${ }^{2}$, G. Thornicroft ${ }^{2}$, N. Quinn ${ }^{3}$, S. Zoppei ${ }^{4}$ and A. Lasalvia ${ }^{4}$

${ }^{1}$ Unit of Psychiatry, IRCCS Istituto Centro San Giovanni di Dio Fatebenefratelli, Brescia, Italy

${ }^{2}$ King's College London, Institute of Psychiatry, London, UK

${ }^{3}$ School of Applied Social Sciences, University of Strathclyde, Glasgow, UK

${ }^{4}$ Department of Public Health and Community Medicine, Section of Psychiatry, University of Verona, Verona, Italy

\section{References}

Aromaa E, Tolvanen A, Tuulari J, Wahlbeck K (2011). Personal stigma and use of mental health services among people with depression in a general population in Finland. BMC Psychiatry 11, 52.

Balestrieri M, Carta MG, Leonetti S, Sebastiani G, Starace F, Bellantuono C (2004). Recognition of depression and appropriateness of antidepressant treatment in Italian primary care. Social Psychiatry and Psychiatric Epidemiology 39, 171-176. 
Barney LJ, Griffiths KM, Jorm AF, Christensen H (2006). Stigma about depression and its impact on help-seeking intentions. Royal Australian and New Zealand College of Psychiatrists 40, 51-54.

Brohan E, Slade M, Clement S, Thornicroft G (2010). Experiences of mental illness stigma, prejudice and discrimination: a review of measures. BioMed Central Health Services Research 10, 80.

Castiello G, Magliano L (2007). Beliefs about psychosocial consequences of schizophrenia and depression: a comparative study in a sample of secondary school students. Epidemiologia e Psichiatria Sociale 16, 163-171.

Corrigan PW, Morris SB, Michaels PJ, Rafacz JD, Rüsch N (2012). Challenging the public stigma of mental illness: a meta-analysis of outcome studies. Psychiatric Services 63, 963-973.

De Leo D, DelloBuono M, Dwyer J (2002). Suicide among the elderly: the long-term impact of a telephone support and assessment intervention in northern Italy. British Journal of Psychiatry 181, 226-229.

Fava GA, Ruini C, Rafanelli C, Finos L, Conti S, Grandi S (2004). Six year outcome of cognitive behavior therapy for prevention of recurrent depression. American Journal of Psychiatry 161, 1872-1876.

Fiorillo A, Malangone C, Del Vecchio V, De Rosa C, Luciano M, Giacco D, Sampogna G, Del Gaudio L, Maj M (2011). The effect of family psychoeducational interventions on patients with depression. European Psychiatry 26 (Suppl. 1), 2209.

Ghio L, Zanelli E, Gotelli S, Rossi P, Natta W, Gabrielli F (2011). Involving patients who attempt suicide in suicide prevention: a focus groups study. Journal of Psychiatric and Mental Health Nursing 18, 510-518.

Gigantesco A, Lega I, Picardi A; SEME Collaborative Group (2012). The Italian SEME Surveillance System of Severe Mental Disorders Presenting to Community Mental Health Services. Clinical practice and epidemiology in mental health, 8: 7-11.

Giupponi G, Sarchiapone M, Pompili M, Sani G, Conca A, Di Fiandra T, Pavan L, Hegerl U, Tatarelli R, Pycha R (2008). Il progetto di prevenzione dell'Alleanza Europea contro la depressione (EAAD). Minerva Psichiatrica 49, 191-201.

Griffiths KM, Christensen H, Jorm AF (2008). Predictors of depression stigma. BMC Psychiatry 8, 25.

Hogan BE, Linden W, Najarian B (2002). Social support intervention - Do they work? Clinical Psychology Review 22, 381-440.

Institute of Medicine (1994). Reducing risks for mental disorders: frontiers for preventive intervention research. In Committee on Prevention of Mental Disorders, Division of Biobehavioral Sciences and Mental Disorders (ed. PJ Mrazek and RJ Haggerty), National Academy Press: Washington, DC.

Jorm AF, Christensen H, Griffiths KM (2005). The impact of beyondblue: the national depression initiative on the Australian public's recognition of depression and beliefs about treatments. Australian and New Zealand Journal of Psychiatry 39, 248-254.
Kanter JW, Rusch LC, Brondino MJ (2008). Depression self-stigma: a new measure and preliminary findings. Journal of Nervous and Mental Disease 196, 663-670.

Lasalvia A, Zoppei S, Van Bortel T, Bonetto C, Cristofalo D, Wahlbeck K, Vasseur Bacle B, Van Audenhove C, van Weeghel J, Reneses B, Germanavicius A, Economou M, Lanfredi M, Ando S, Sartorius N, Lopez-Ibor JJ, Thornicroft G, the ASPEN/INDIGO Study Group (2013). Global pattern of experienced and anticipated discrimination reported by people with major depressive disorder: a cross-sectional survey. Lancet 381, 55-62.

Molinari E, Pagnini F, Castelnuovo G, Lozza E, Bosio CA (2012). A new approach for psychological consultation: the psychologist at the chemist's. BioMed Central Public Health 12, 501.

NIMH (1998). Priorities for Prevention Research at NIMH: A Report by the National Advisory Mental Health Council Workgroup on Mental Disorders Prevention Research. NIH Publication No. 98-4321.

Paykel ES, Hart D, Priest RG (1998). Changes in public attitudes to depression during the defeat depression campaign. British Journal of Psychiatry 173, 519-522.

Poma SZ, Grossi A, Venturini M, Contessa C, Toniolo E (2011). Setting up suicide prevention plans at the local level: methodology of focus groups with stakeholders. Journal of Community Psychology 39, 755-760.

Quinn N, Knifton L, Goldie I, Van Bortel T, Dowds J, Lasalvia A, Scheerder G, Boumans J, Svab V, Lanfredi M, Wahlbeck K, Thornicroft G (2013). Nature and impact of European antistigma depression programmes. Health Promotion International, (Epub ahead of print). 10.1093/heapro/das076

Rucci P, Piazza A, Menchetti M, Berardi D, Fioritti A, Mimmi S, Fantini MP (2012). Integration between Primary Care and Mental Health Services in Italy: Determinants of Referral and Stepped Care. International journal of family medicine, 2012:507464.

Ruini C, Ottolini F, Tomba E, Belaise C, Albieri E, Visani D, Offidani E, Caffo E, Fava GA (2009). School intervention for promoting psychological well-being in adolescence. Journal of Behavior Therapy and Experimental Psychiatry 40, 522-532.

Scocco P, Castriotta C, Toffol E, Preti A (2012). Stigma of Suicide Attempt (STOSA) scale and Stigma of Suicide and Suicide Survivor (STOSASS) scale: two new assessment tools. 200: 872-878.

Vega WA, Rodriguez MA, Ang A (2010). Addressing stigma of depression in Latino primary care patients. General Hospital Psychiatry 32, 182-191.

Warner R (2008). Implementing local projects to reduce the stigma of mental illness. Epidemiologia e Psichiatria Sociale 17, 20-25.

Watson AC, Otey E, Westbrook AL, Gardner AL, Lamb TA, Corrigan PW, Fenton WS (2004). Changing middle schoolers' attitudes about mental illness through education. Schizophrenia Bullettin, 30:563-572.

Zoppei S, Lasalvia A (2011). Anti-stigma campaigns: really useful and effective? A critical review of the anti-stigma initiatives conducted in Italy. Rivista di Psichiatria 46, 242-49. 